Check for updates

The BMJ

Cite this as: $B M J 2020 ; 371: m 4499$ http://dx.doi.org/10.1136/bmj.m4499 Published: 18 November 2020

\section{Report of UK's pandemic preparedness leaves questions unanswered, says doctor}

\author{
Clare Dyer
}

An NHS doctor who launched legal action in the High Court to force the Department of Health and Social Care (DHSC) to publish a 2016 report into an exercise wargaming a future pandemic has dropped the case after the report was finally published on the department's website. ${ }^{1}$

The report on Exercise Cygnus, the simulation of a fictitious influenza pandemic, warned that “the UK's preparedness and response, in terms of its plans, policies, and capability, is currently not sufficient to cope with the extreme demands of a severe pandemic that will have a nationwide impact across all sectors."

Moosa Qureshi filed an application in April for judicial review of the government's refusal to publish the report. ${ }^{2}$ A version of it was leaked to the Guardian the following month. Qureshi and freelance journalist Tommy Greene also made a Freedom of Information (FOI) Act request for the report. The court turned down the application for permission to apply for judicial review, partly because the FOI request should have been decided before the case could come to court. But the government repeatedly delayed replying, arguing that it needed more time to weigh up the public interest.

An appeal against the refusal of the judicial review application was to be heard on 19 November. In the meantime, the information commissioner gave the DHSC a deadline to publish the report and it was published on the department's website. ${ }^{3}$ The published report contains limited information and goes no further than the version leaked to the Guardian. But the DHSC has assured Qureshi and Greene that the department holds no further reports detailing the findings of Exercise Cygnus, leaving the pair unable to take the legal action forward.

It remains an open question, however, whether other bodies that took part in the exercise have further material.

Qureshi told The BMJ, "The health secretary has wasted taxpayers' money evading transparency on a national pandemic exercise at a time of civil crisis. He has finally disclosed Public Health England's report into Cygnus and has confirmed that the DHSC holds no further reports from Cygnus, but important questions remain around the UK's capacity to deal with a major pandemic.

"We believe that more data exist on the UK's pandemic preparedness, and that disclosure and collaborative peer review of these data are essential for the healthcare and scientific community to manage covid-19 and future pandemics effectively." He said on the campaign's crowdfunding page, “We remain determined to pursue data on the UK's pandemic preparedness because transparency is fundamental to good healthcare, good science, and good democracy. We aim to expand our campaign dramatically over the coming weeks and months."4

Tessa Gregory, a partner in law firm Leigh Day, which represents Qureshi and Greene, said, “Our clients have been appalled by the government's lack of transparency in relation to this matter. They are determined to continue their fight to reveal how and if the recommendations from Exercise Cygnus were implemented, as that remains key to the way in which the government is responding to the current pandemic."

Department of Health and Social Care. UK pandemic preparedness. October 2020. www.gov.uk/government/publications/uk-pandemic-preparedness.

2 Dyer C. Pandemic preparedness: doctor leads campaign for UK government to release report. BMJ2020;369:m1732. doi: 10.1136/bmj.m1732 pmid: 3234998

3 lacobucci G. Pandemic preparedness: Government must release 2016 report, says information commissioner. BMJ2020;371:m3953. doi: 10.1136/bmj.m3953 pmid: 33046458

4 Qureshi M. What are the government hiding about their response to covid-19? Crowdjustice. www.crowdjustice.com/case/jrcovid19 